\title{
INTERBANK LIQUIDITY CRUNCH AND THE FIRM CREDIT CRUNCH: EVIDENCE FROM THE 2007-2009 CRISIS ${ }^{1}$
}

\section{Rajkamal Iyer}

Massachusetts Institute of Technology

\section{Samuel Lopes}

European Central Bank

José-Luis Peydrón

Universitat Pompeu Fabra and Barcelona GSE

\section{Antoinette Schoar}

Massachussetts Institute of Technology and NBER

\section{April 2013}

\footnotetext{
${ }^{1}$ We thank two referees, the Editor and Victoria Ivashina for helpful comments and suggestions. Francesca Rodriguez-Tous provided excellent research assistance. We would also like to thank Nittai Bergman, P.Iyer, Asim Khwaja, Atif Mian and Manju Puri,for their suggestions. Any views expressed are only those of the authors and should not be attributed to the Bank of Portugal, the European Central Bank or the Eurosystem. E-mails: riyer@mit.edu; Samuel.Lopes@ecb.europa.eu; jose.peydro@upf.edu (corresponding author), and aschoar@mit.edu.

${ }^{2}$ Corresponding author: José-Luis Peydró. Address: C/ Ramon Trias Fargas 25-27, Office 20.224, 08005, Barcelona (Spain). Phone: (+34) 935421756. E-mail: jose.peydro@upf.edu
} 


\begin{abstract}
We study the credit supply effects of the unexpected freeze of the European interbank market, using exhaustive Portuguese loan-level data. We find that banks that rely more on interbank borrowing before the crisis decrease their credit supply more during the crisis. The credit supply reduction is stronger for firms that are smaller, with weaker banking relationships. Small firms cannot compensate the credit crunch with other sources of debt. Furthermore, the impact of illiquidity on the credit crunch is stronger for less solvent banks. Finally, there are no overall positive effects of central bank liquidity, but higher hoarding of liquidity.
\end{abstract}

Keywords: Credit crunch; banking crisis; interbank markets; access to credit; flight to quality; lender of last resort; liquidity hoarding.

JEL codes: G01; G21; G28; G32. 
The developed world has experienced the worst financial crisis since the Great Depression which was at its core a banking crisis. The main channel through which a banking crisis may affect the real economy relates to the ability of the private sector to access the credit needed to fund investment and consumption. Hence, a key question at the heart of the current financial crisis is whether and how the sudden dry up in bank liquidity impacted the availability of credit. A drop in liquidity for some banks may have a direct transmission effect on the supply of credit for firms if firms are unable to substitute with other sources of finance such as loans from other banks, trade credit or other forms of debt. Furthermore, this channel could be especially relevant in the context of smaller younger (entrepreneurial) firms which usually find it difficult to access funds from other sources since they are more opaque and thus mainly rely on existing banking relationships.

In this paper we study whether and how banks cut back on lending supply when faced with a negative liquidity shock. What are the margins along which banks adjust their loan portfolios in response to the crisis, e.g. do we observe credit supply contractions across all types of borrowers, or do they disproportionally cut back credit for entrepreneurial (smaller) firms? Could firms substitute funds from alternative sources? In addition, is there a differential effect across different types of banks depending on their solvency? How does public provision of liquidity by the central bank affect the evolution of the shock?

One of the main problems in empirically addressing the questions raised above is the difficulty of identifying the causal impact of a bank liquidity shock on loan supply. Liquidity shocks to banks are usually correlated with an underlying change in the overall 
economic environment, which might adversely affect not only the supply of credit but also the demand for loans from firms and, in general, firm risk. Moreover, even if there is a credit supply reduction from an individual financial institution, it would only translate into credit constraints, if firms cannot substitute a credit reduction from the more affected banks with credit from other, less affected, banks (or even from other sources of credit).

To tackle these identification challenges, we use the initial exogenous and unexpected shock to the interbank markets in August 2007. The crisis started in August 2007 in Europe when the interbank market, a crucial source of liquidity for banks in Europe ${ }^{3}$ started experiencing significant tensions - for example, interbank loan spreads went significantly up, and the European Central Bank had to inject large amounts of liquidity. ${ }^{4}$ The onset of this liquidity crisis was an unexpected shock across all European countries and not related to the Portuguese banks, especially as these banks were not investing in US subprime or in the US dollar market. Furthermore, the bank capital regulation in Portugal did not encourage setting up of off-balance sheet vehicles (Acharya and Schnabl 2010) and there was no real estate bubble in Portugal. ${ }^{5}$

\footnotetext{
${ }^{3}$ See for example Upper (2006).

${ }^{4}$ On the $9^{\text {th }}$ of August 2007, the ECB had to inject a significant amount of liquidity to banks ( $€ 95$ billion) due to a dry up in the interbank markets, and on the following week the ECB injected an additional $€ 150$ billion (see e.g. ECB Financial Stability Review 2009, and Cecchetti 2008).

${ }^{5}$ Portuguese banks were mainly borrowing from other European banks (BIS 2012) and had net inflows of foreign capital and, therefore, they did not belong to a country with large current account surpluses that need "safe assets" notably from US as e.g. China or Germany (see Acharya and Schnabl 2010). Moreover regulation for Portuguese banks made it unattractive to set-up of off-balance sheet vehicles to arbitrage capital regulation (see also Acharya and Schnabl 2010; Brunnermeier 2009; Covitz, Liang, and Suarez forthcoming). Furthermore, between 1996 and 2006 the accumulated real valuation of housing prices grew only $10 \%$ in Portugal as compared to more than 80 percent in the United States, Holland and Greece, 110 percent in Spain, 140 percent in the United Kingdom and 180 percent in Ireland (Nota Temática CDG 2011).
} 
We have complete bank balance sheet data, including the interbank borrowing of each of the banks in the system, thus we can observe which banks were more affected by the interbank market tensions. We exploit the interbank liquidity dependence (borrowing) for each bank before the crisis, which gives significant variation in bank liquidity shocks induced by the unexpected European interbank crisis. It is important to note that bank dependence to interbank funds before the crisis (2007:Q2) is not correlated with measures of bank profitability, risk or capital. Moreover, we use an exhaustive dataset from the Portuguese central bank that has detailed loan level data on all corporate loans made by each bank in Portugal, including all the loans made to small and medium size firms. Finally, we have key balance sheet characteristics for the firms, in particular firm size, age, total debt, profitability and interest coverage ratio.

We use a difference-in-difference approach comparing lending before and after the crisis among banks with different liquidity shocks (proxied by the interbank borrowing ratio before the onset of the crisis, specifically in May 2007). ${ }^{6}$ We control for observed and unobserved firm heterogeneity in loan demand, quality and risk by using firm fixedeffects. ${ }^{7}$ That is, for the same firm, we compare the change in lending by more and less affected banks before (2007:Q2) and after the crisis (2009:Q2).

We find that a firm that ex-ante borrows more from banks with a higher interbank borrowing ratio in 2007:Q2 experiences, on average, a greater reduction in credit during the crisis. One could be concerned that this effect is driven by banks with higher

\footnotetext{
${ }^{6}$ There is a large theoretical literature on the bank lending channel. See for example Freixas and Rochet (2008), and Tirole (2006).

${ }^{7}$ See Khwaja and Mian (2008).
} 
interbank borrowing lending more to firms with lower loan demand or with higher risk during the crisis. However, even when we analyze credit change within a borrower, we find that - for the same firm - the greater decline in credit comes from the bank with a higher ex-ante interbank borrowing ratio. In terms of economic magnitudes we find that a $10 \%$ increase in borrowing in the interbank markets prior to the crisis leads to a further $4 \%$ reduction in firm credit availability during the crisis.

We then examine the heterogeneous effects across firms. Controlling for firm fixed effects, we find that the magnitude of credit supply reduction due to the interbank liquidity exposure is significantly higher economically (and statistically) for firms that are (i) smaller in size (as measured by both total assets or number of employees), (ii) younger (as measured by the age of incorporation), and (iii) with lower banking relationship (as measured by the firm-bank credit volume before the crisis). Interestingly, for the large firms results are not statistically significant anymore - in fact, the coefficient drops to zero. That is, we find a credit supply contraction due to bank liquidity, but only for entrepreneurial (smaller and younger) firms.

We also find that banks with higher interbank borrowing are less likely to start a new lending relationship with small firms. Therefore, our results suggest that entrepreneurs' access to new credit in the banking system (the extensive margin) is worsened by bank liquidity problems. Moreover, the likelihood of termination of an existing lending relationship is also higher for banks with higher interbank borrowing. However, interestingly, we find that higher strength of an existing lending relationship lowers the effect of higher interbank borrowing on the likelihood of loan termination. 
This effect is similar in magnitude for both small and large firms. These results suggest that banking relationships mitigate credit supply restrictions across all type of firms.

On firm characteristics that proxy for quality and risk, such as firm return on assets and loan interest coverage, we find that banks cut credit supply across the board with respect to firm profits. However, surprisingly, we find that banks do not cut (in fact, support) credit supply to weaker firms in terms of low loan interest coverage. A possible explanation is loan ever-greening or zombie lending (see Caballero, Hoshi, and Kashyap 2008), i.e. a credit reduction to these firms might increase potential loan defaults which could in turn increase capital requirements for banks and/or the likelihood of firing the bank top managers.

An important question for public policy is whether and how the public liquidity coming from central banks, in this case the European Central Bank, helped in alleviating the credit supply tensions. As the Euro area is a bank-dominated economy, the ECB mainly intervened by providing ample public liquidity to banks. Our evidence suggests that the negative impact of bank illiquidity on credit supply is stronger for banks with higher insolvency (higher non-performing loans). This suggests that bank fundamentals can amplify the extent of the initial illiquidity shock through an interaction between bank solvency and liquidity. ${ }^{8}$ Consistent with this, we find limited positive overall effects from central bank liquidity on credit supply. In particular we find that banks with higher overall liquidity provision by the central bank increase credit supply. However, this effect is partially reduced by higher ex-ante interbank borrowing. We also find that banks with

\footnotetext{
${ }^{8}$ See Rochet and Vives (2004) for models showing interactions between bank solvency and illiquidity.
} 
higher interbank borrowing do not cut back on their total assets but increase their ratio of liquid assets. This suggests that banks with higher liquidity problems use the public liquidity from the central bank (and the reduction of credit supply) to hoard liquidity.

A crucial question for the impact on firms is whether firms can compensate a reduction of credit supply from one (affected) bank by accessing funds from other, less affected, banks, or in general from other sources of finance as trade credit or other forms of debt. If firms could substitute credit easily, they would not be affected by the credit supply reduction from some of the affected banks and, hence, the overall effects of the crisis would be significantly small. We find that, on average, firms are not able to perfectly substitute credit supply reductions, neither with higher credit from less affected banks nor with other sources of debt. Hence, the credit supply reduction in the crisis was binding for entrepreneurial firms.

A contribution to the literature is that we identify a causal link from a negative shock to bank liquidity (interbank crunch) to a credit supply reduction for firms, finding that the effects are strong and binding only for small (entrepreneurial) firms. Furthermore, we find that the impact of bank illiquidity on credit supply varies by bank solvency. Consistent with this finding, we do not find overall positive effects of central bank liquidity for these banks, but higher hoarding of liquidity.

The rest of the paper proceeds as follows. Section 1 discusses the related literature. Section 2 presents the datasets and the empirical strategy. Section 3 presents and discusses the results. Section 4 concludes. 


\section{Related Literature}

Our results contribute to several strands of literature. Our results add to the literature that examines whether bank liquidity shocks are transmitted to their customers through a change in lending (see Paravisini 2008; Khwaja and Mian 2008; Schnabl 2012;). ${ }^{9}$ These papers also use credit register data and firm fixed effects to identify credit supply changes, but - as these papers do not use firm level balance-sheet variables (notably size and total debt) - they do not analyze the impact of the credit crunch to entrepreneurial firms and whether the credit shock is binding or not. In addition, our paper also examines the interactions between bank solvency and illiquidity on the credit crunch to firms and the role of the central bank in reducing the credit tensions.

Our paper is also related to the strands of literature that study in general the costs of banking crises (Bernanke 1983; Bernanke and Lown 1991; Peek and Rosengreen 2000; Ongena, Smith, and Michalsen 2003; Calomiris and Mason 2003; Gan 2007; Dell'Ariccia, Detragiache, and Rajan 2008; Iyer and Peydró 2011). In particular, our paper directly complements other papers that empirically examine the costs of the 200709 crisis, in particular Ivashina and Scharfstein (2010) analyze large U.S. firms, and Puri, Rocholl, and Steffen (2011) analyze German households.

Our paper also contributes to the literature that examines the liquidity hoarding by banks and disruptions in the interbank market during the crisis. On the empirical front, Ashcraft, McAndrews, and Skeie (2011) present empirical evidence on precautionary hoarding, reluctance of banks to lend coupled with extreme rate volatility in the U.S fed

\footnotetext{
${ }^{9}$ For the impact of monetary policy on credit supply, see Kashyap and Stein (2000) and Jiménez, Ongena, Peydró and Saurina (2012a and 2012b).
} 
funds market during the 2008-09 crisis. Acharya and Merrouche (2012) find evidence that suggests precautionary hoarding of liquidity to be a prime driver of liquidity demand by large settlement banks in the U.K during the crisis. On the theoretical front, Diamond and Rajan (2011) and Holmstrom and Tirole (2011) show there can be a credit crunch due to liquidity hoarding by banks and central bank liquidity assistance may therefore not increase credit supply to firms. Acharya and Skeie (2011) show that banks hoard liquidity and decrease term lending during the crisis, which in the extreme can lead to a complete breakdown of the interbank market. More broadly, our paper also contributes to the theoretical literature that shows firms hoard liquid assets and reduce risk-sharing during a crisis (Caballero and Krishnamurthy 2008).

\section{Data and Empirical Strategy}

We analyze the impact of the interbank liquidity crisis of 2007-09 on the supply of credit for non-financial firms. As explained in the Introduction, the main identification problems are the following: a bank liquidity shock can be in general correlated at the bank level with borrower characteristics such as firm risk, net worth and loan demand. In particular, the interbank borrowing ratio is an endogenous choice, which may reflect underlying investment opportunities of the bank. Moreover, the key, related, identification problem is that credit may be reduced in a crisis not only due to credit supply restrictions but also due to changes in firm loan demand, net worth and risk. Finally, even if an affected bank is restricting credit, the firm, especially if large, could obtain credit through other less affected banks, or even substitute with other sources of credit. 
For identification, therefore, we exploit the shock in the interbank markets at the start of the crisis and use comprehensive loan level data to isolate the credit supply channel.

We exploit the bank liquidity shock induced by the unexpected severe problems in the interbank market that started on the $9^{\text {th }}$ of August 2007. Interbank spreads immediately went up. In addition, interbank market credit volume went down in Europe, especially cross-border. Moreover, regulation for Portuguese banks made it unattractive to set-up of off-balance sheet vehicles funded by Asset Backed Commercial paper (see Acharya and Schnabl 2010). Hence the freeze in the ABCP market did not have a direct effect on Portuguese banks. Furthermore Portugal did not witness a huge real estate boom. The real valuation of housing prices grew only $10 \%$ in Portugal over the years 1996-2006. Thus, it seems unlikely that a run on the housing market had a huge impact on the solvency of Portuguese banks.

Given all these developments in the European interbank markets, we measure the susceptibility to the shock by using the interbank borrowing ratio of each bank before the onset of the crisis, in particular on May 2007. We also use in some regressions the part of interbank borrowing coming from abroad, and the part of borrowings from other banks in Portugal, since, as argued above, the general dry-up of international interbank markets was not particular to Portugal. ${ }^{10}$

\footnotetext{
${ }^{10}$ Since the aggregate rate of savings in Portugal is very low, banks have to finance significantly abroad. This, in turn, created a vulnerability of Portuguese banks to a dry up of liquidity in international markets. This dependence was therefore not related to the dollar shortage or to investments in US subprime. See the BIS dataset on the specific dependence of Portuguese banks (see http://www.bis.org/statistics/about_banking_stats.htm).
} 
We, moreover, use the entire lending to non-financial firms in Portugal from 2007:Q2 to 2009:Q2. ${ }^{11}$ We have access to the records on all granted loans, which are recorded by the Bank of Portugal, which is the regulator and supervisor of the banking system in Portugal. For these purposes, we employ the information in the credit register (Central Credit Register, CRC in Portuguese) which contains confidential and very detailed information at the loan level on all commercial and industrial (C\&I) loans granted to all non-financial publicly limited and limited liability companies by all banks operating in Portugal. The dataset is comprehensive, as the reporting threshold for a loan is only 50 Euros. Given that we consider only business loans, this threshold alleviates any concerns about unobserved changes in bank credit to small entrepreneurial firms, which is key to analyze the credit supply restrictions to entrepreneurs. ${ }^{12}$

We match the credit register data compiled at a quarter frequency with (i) complete bank balance-sheet variables, with monthly frequency, in particular bank size, profits, liquidity, non-performing loans, capital and interbank borrowing ${ }^{13}$ and (ii) some firm balance-sheet variables that we have access to (Banco de Portugal Central Balance-Sheet Database), in particular firm identity, industry, location, juridical nature, total assets, number of employees, age of incorporation, profits, interest expenses and total debt, with yearly frequency.

\footnotetext{
${ }^{11}$ For robustness, we also use other time windows (not reported results).

${ }^{12}$ Incomplete coverage of the widely used U.S. (National) Survey of Small Business Finances or the Loan Pricing Corporation may complicate any analysis of bank credit provision, especially for entrepreneurial finance. Note that even some credit registers, as for example the one in Germany operated by the Bundesbank, only has loans over a million euros.

${ }^{13}$ For few banks, we do not have data on some of these variables.
} 
We aggregate all the different loans between a firm-bank pair in 2007:02 and also in 2009:Q2. Hence, we have a measure of total (committed) credit exposure between each firm-bank pair before and after the onset of the crisis. ${ }^{14}$ Our main loan variable is the change in the $(\log )$ level of all the loans for each firm-bank pair between 2009:Q2 and 2007:Q2.

The empirical strategy we use is the following. ${ }^{15}$ We use a difference-in-difference approach comparing lending before (2007:Q2) and after the crisis (2009:Q2) among banks with different levels of interbank borrowing as of 2007:Q2 (before the crisis). To account for unobserved heterogeneity in firm loan demand, quality and risk we saturate the specification with firm fixed effects. Our identification, therefore, entirely comes from firms which were borrowing from two different banks before the crisis. In this way, we can isolate the causal impact of the interbank liquidity crunch on the change in credit supply by comparing the change in lending for the same firm from banks with higher visà-vis lower interbank liquidity borrowing before the crisis.

To put it differently, we examine the same firm that is borrowing from two different banks and examine whether the firm experiences a higher drop in credit from the bank with a higher fraction of borrowing from the interbank market before the onset of the crisis. Thus we have firm fixed effects, and we examine the magnitude of change in credit between 2009:Q2 and 2007:Q2 based on the interbank borrowing levels of the

\footnotetext{
${ }^{14}$ Part of the committed loans in 2007:02 may be withdrawn later by the firm, for example by drawing down of a credit line. In fact, the growth of withdrawn (used) credit growth during the crisis was significantly reduced, but did not turn out negative until 2010.

${ }^{15}$ See Khwaja and Mian (2008).
} 
lending banks before the onset of the crisis. ${ }^{16}$ Hence, if we find different, significant, results, it will be because the interbank shock is affecting banks' loan supply, and not because heterogeneity in firm loan demand and risk is driving the results.

Once we test whether there is a credit supply reduction, we want to understand whether all banks with ex-ante interbank borrowing cut lending similarly or whether the illiquidity (and therefore the reduction in credit supply) was higher for the less solvent ones. In addition, we want to analyze the effects of central bank lending and the rebalancing of the portfolio of the banks between loans and liquid assets.

Moreover, we want to understand whether banks cut credit supply across the board, or whether the credit supply restrictions were stronger for some type of firms - for example, entrepreneurial firms. That is, controlling for observed and unobserved heterogeneity in firm risk, quality and demand (firm fixed-effects), we analyze whether the impact of the negative bank liquidity shock on credit is related to firm characteristics.

Finally, even if we identify a credit supply reduction from affected banks, we then analyze whether firms can substitute and obtain more credit from other, less affected, banks - or even through other sources of credit such as trade credit and market debt. If that was the case, the credit supply reduction would not be binding, and the costs of the banking crisis would be small.

Summarizing our empirical strategy, the baseline regression at the loan-level is the following:

\footnotetext{
${ }^{16}$ See Bertrand, Duflo, and Mullainathan (2004) and Khwaja and Mian (2008).
} 


$$
\Delta \log \text { Credit }_{b i}=\alpha_{i}+\text { Interbank Borrowing }_{b, 2007: Q 2}+\delta \text { Controls }_{b i}+\varepsilon_{b i}
$$

where the dependent variable $\Delta \log$ Credit $_{b i}$ is the change in (log) granted credit from bank $b$ to firm $i$ between 2009:Q2 and 2007:Q2, the main independent variable Interbank Borrowing $\mathrm{b}, 2007: \mathrm{Q} 2$ is the interbank borrowing ratio as of 2007:Q2, $\alpha_{i}$ are the firm fixed effects (a dummy for each firm) and Controls $_{b i}$ are the main controls, which are bank characteristics as bank size, liquidity ratio, non-performing loan ratio, capital ratio and return on asset ratio. We also analyze interactions of Interbank Borrowing $g_{b, 2007: Q 2}$ with bank variables (as e.g. NPL ratio, capital ratio and central bank borrowing) and firm variables (as e.g. firm size in terms of log total assets or number of employees, age, ROA, firm loan coverage ratio and bank-firm previous credit volume). Finally, we analyze a similar regression at the firm-level where the dependent variables are either the change in $(\log )$ total bank credit between 2009:Q2 and 2007:Q2 from all the banks to firm $i$, or the change in $(\log )$ total debt between 2009:Q2 and 2007:Q2 from all the sources of debt from firm $i$, and the main independent variable is for firm $i$ the weighted (by the credit granted by each bank $b$ to the firm $i$ as of 2007:Q2) average of Interbank Borrowing ${ }_{i, 2007: Q 2}$.

\section{Empirical Results}

We first examine bank credit growth experienced by Portuguese non-financial firms in the period before and after the crisis. As it can be clearly seen from Graph 1, we find a significant decline in credit growth in the crisis period. While the graph suggests that credit growth was significantly affected by the crisis, this graph also includes drawdown of committed lines of credit by firms. This could potentially explain the increase in credit 
growth reported in the period immediately after August 2007 and why credit growth was still positive in 2009, which could be driven by firms drawing on their lines of credit (see also Ivashina and Scharfstein 2010). Another factor that could explain the data is that during a financial distress, firms cannot access market finance thereby increasing their demand for bank loans (see Bernanke, Gertler, and Gilchrist 1996).

While Graph 1 shows a decline in credit growth, when looking at it in conjunction with the graph of interbank borrowing by banks from interbank markets (Graph 2), we find that both these graphs look similar, though it is interesting to notice that interbank borrowing decreases before than firm credit growth. That is, there seems to be a decline in the interbank borrowing and a posterior decline in the credit to firms. This suggests that, potentially, the dry up in access to liquidity in the interbank markets could be an important factor affecting the credit growth of firms. ${ }^{17}$ However, to clearly understand whether a dry up in interbank market liquidity was an important cause of the decline in the credit supply for firms, one needs to be able to disentangle the loan demand effects by firms. That is, the drop in credit growth could primarily be due to firms demanding fewer funds from banks once the crisis hits given the grim economic outlook and also to banks lending less to firms because the latter ones could be riskier.

Table 1 presents the summary statistics of the data. For each firm in the sample, we find that on average they have three banking relationships outstanding before the crisis (the banking relationships are defined as on May 2007 for firms with outstanding loans).

\footnotetext{
${ }^{17}$ As said in the previous sections, the cost of interbank finance immediately went up in the crisis and stayed high since then. Therefore, interbank borrowing became more costly and, hence, there was a negative shock to bank liquidity.
} 
Examining the number of firm bank pairs, in total we have 293,896 pairs. As stated earlier, we define a pair based on the firm borrowing from a bank as of 2007:Q2. Thus if firm A borrows from bank B and C in 2007:Q2, we would record two observations, one pair would be firm A with bank B and the other pair would be firm A with bank C. Examining the credit growth experienced by each firm-bank pair, we find that on average there was a 16\% lower credit growth between the period of 2009:Q2 and 2007:Q2. We also find that when we limit the pairs to firms that have at least 2 banking relationships, we find a total of 220,406 pairs as the large majority of firms in Portugal borrow from more than one bank, which is key for our empirical strategy as discussed in the previous section.

At the bank level, we select the 84 largest banks in the sample, which constitutes around $90 \%$ of the total lending in the Portuguese banking system. ${ }^{18}$ We find that on average the fraction of borrowing as a percentage of total assets from the interbank market is $25 \%$, further decomposing the interbank borrowing based on borrowing from domestic banks and borrowing from foreign banks, we find that the percentage of borrowing from foreign banks is $27 \%$ (from only 34 banks) and from domestic banks is $12 \%$. The fact that banks rely substantially on foreign interbank borrowing is important as this source immediately dried up with the onset of the crisis (for the reduction of crossborder interbank finance, see ECB Financial Integration Report 2009). ${ }^{19}$

In terms of bank asset size, we find that the average log of size of the bank in the sample is 19.90 . The fraction of liquid assets held by banks before the crisis is on average

\footnotetext{
${ }^{18}$ For some banks, some balance sheet variables are missing.

${ }^{19}$ See also http://www.bis.org/statistics/about_banking_stats.htm.
} 
$29 \%$. We also find that the return on operating assets (ROA), non-performing loan ratio (NPL), and capital ratio of banks are $0.5 \%, 0.9 \%$, and $11 \%$, respectively.

\subsection{The effect of interbank borrowing dependence on credit supply for firms}

We first examine the effect of the interbank market shock on credit availability. In Table 2, column 1, we examine whether banks with a higher fraction of interbank borrowing cut back more on credit to firms between 2007:Q2 and 2009:Q2. The dependent variable is the change in $(\log )$ total committed lending for each firm-bank pair. As results in column 1 show, using the entire lending to firms, we find that there is a significant drop in credit if the lending bank has a higher fraction of borrowing from the interbank market. Note that we measure the interbank borrowing in the quarter before the start of the crisis and the standard errors are clustered at the bank level.

In column 2 and in general for the rest of the paper, as argued in the empirical strategy section, we restrict the sample to firms that were borrowing at least from two different banks in 2007:Q2. The coefficient of interbank borrowing is almost identical to column 1, which suggests that selecting on firms with multiple lending is not changing the credit channel impact. In column 3, we include controls for the bank characteristics before the crisis in addition to the level of interbank borrowing, finding that interbank borrowing is still statistically significant at $1 \%$, but the coefficient significantly drops from -0.55 to -0.32 .

While in column 1, 2 and 3, we find that the magnitude of reduction in credit is related to the level of interbank borrowing for a firm-bank pair, one could be concerned that some firms with a lesser demand for credit or with higher risk were borrowing more 
from banks with higher level of interbank borrowing. If that was the case, the reduction in credit rather than a supply side reduction by banks would be then driven by lower credit demand volume and/or quality, i.e. those firms would match with banks with higher level of interbank borrowing. To address the previous concern, we include firm fixed effects to control both for heterogeneity in observable and unobservable characteristics. In effect, we examine whether, for two banks lending to the same firm in 2007:Q2, there is a higher reduction in credit from the banks with a higher level of interbank borrowing. Hence, we are able to hold the observed but also the unobserved loan demand, quality and risk of the firm constant and, therefore, we are able to isolate the loan supply effect.

As the results in column 4 shows, we find very similar magnitudes to those reported in column 1 and 2. In column 5, we include bank controls and again find similar results to those reported in column 3. Despite that the coefficients are similar, once we include firm fixed effects the absolute value of the coefficients increase marginally, hence accounting for the loan demand channel strengthen quantitatively the credit supply channel, but economically the change is very small, thus the firm-bank matching does not seem very relevant in this context. ${ }^{20}$

All in all, we find that the dependence to interbank funds reduces the credit supply. In terms of economic magnitudes we find that a $10 \%$ increase in interbank borrowing of the lending bank results in a $3.7 \%$ reduction in credit availability for the firm.

\footnotetext{
${ }^{20}$ This implies that the coefficient of the firm level regression also show the impact of credit supply restrictions, see Jiménez, Mian, Peydró, and Saurina (2012).
} 
In column 5, we also find that banks that are larger in size are less likely to cut credit, thus suggesting that larger banks may have access to alternative sources of liquidity to meet their funding needs. We also find that banks with higher non-performing loans are less likely to cut back on credit. This is surprising as one would expect banks with higher non-performing loans to cut back more as their capital constraints would be more binding. However, it could be possible that these banks are also more likely to engage in loan ever-greening. ${ }^{21}$ Finally, in column 6 , we control for the credit between the firm and the bank in 2007:Q2 and find similar results. All in all, the results suggest that the negative liquidity shock induced a credit supply reduction to businesses. ${ }^{22}$

\subsection{Do banks reduce credit supply more to some firms?}

We have seen that on average there is a credit supply reduction. In Table 3 we study whether the credit supply reduction is stronger for some type of firms. As we still want to control for the level impact of firm risk and loan demand we still use firm fixed effects, and introduce interaction effects between interbank borrowing and some firm characteristics. In particular, we examine the interaction effects related to firm size (as measured by total assets and number of employees), firm age (as measured by the age of incorporation of the firm), firm riskiness/ weaknesses (as measured by the loan interest coverage), firm profitability (as measured by the return on assets), and relationship

\footnotetext{
${ }^{21}$ See also Albertazzi and Marchetti (2011).

${ }^{22}$ While we examines changes in credit for the same firm by different banks based on their level of interbank exposure, one could still be concerned about omitted variables driving the average effect. The differential effect in credit reduction across different types of firms (small versus large) provides better identification.
} 
banking (as measured by the credit volume of the bank to the firm before the onset of the crisis).

We find that the magnitude of the credit supply reduction due to the interbank liquidity shock is significantly higher economically and statistically for firms that are smaller in size (column 1), younger (column 2) or with a lower relationship with the bank (column 6). We also find that firms with lower number of employees face a higher reduction in credit supply (significant at $11 \%$ ). That is, we find a credit supply contraction due to bank illiquidity, and the contraction effects are significantly stronger for entrepreneurial (smaller and younger) firms and also for firms with weaker banking relationships.

On firm characteristics that proxy for quality and risk such as firm return on assets and loan interest coverage, we find that banks cut credit supply across the board with respect to firm profits (column 5). However, surprisingly, banks were supporting weaker firms (firms with low loan interest coverage). A possible explanation could be that banks support weaker firms in order to reduce potential loan defaults which could imply increases of capital requirements for banks, i.e. banks may ever-green loans (see Caballero, Hoshi, and Kashyap 2008).

\subsection{Is there a credit supply contraction for large firms?}

The results from Table 2 and 3 suggest that the liquidity dry up in the interbank market had a significant effect on credit supply, and that the impact is stronger for smaller firms. The next question that arises is whether the reduction in loan supply is only for small firms or also for large firms? To examine this question, we estimate the 
regression in table 2 column 5 (our benchmark specification) introducing a new variable based on firm size, either measured by total assets or by number of employees (Table 4). Note that in all the regressions that we report, we limit ourselves to firms that have at least two banking relationships and we control for firm fixed effects.

In Table 4, column 1, we estimate the reduction in credit supply of ex-ante interbank borrowing depending on the firm total assets lower or higher than the threshold of one million Euros as of December 2006. We create two separate dummies. One dummy for firms with assets lower than the specified threshold, one dummy for firms with assets higher than the specified threshold. We then interact the dummies with interbank borrowing level. In columns 2 and 3, we use higher thresholds for total assets. In columns 4 to 6 , we create dummies based on number of firm employees.

As results show, in column 1, we find that the effect of interbank borrowing on credit growth is statistically significant for firms with total assets lower than one million. We also find that the magnitude of the effect is much higher for smaller firms (-0.50 vs. 0.21 for firms with assets higher than one million). An $\mathrm{F}$ test of the difference in coefficients is significant at $10 \%$ level. In column 2 and 3, we re-examine the effect based on the thresholds of 10 million euros and 100 million euros (as of December 2006), respectively, finding similar results. Interestingly, we find that coefficient on the dummy for firms higher than the threshold is progressively smaller as we increase asset size. That is, firms of larger size do not experience a reduction in credit supply even if their bank has a high level of interbank borrowing before the crisis. This result is even clearer in column 3 when looking at the dummy for firms with assets greater than 100 million euros 
as of December 2006. The coefficient is not statistically significant and, in fact, becomes positive.

As results show, we find that the effect of interbank borrowing of banks on credit supply is only significant for smaller firms. Note that this effect is not driven by the ability of large firms to substitute credit from other banks as we are looking at the change in credit within firm-bank pair. This suggests that banks experiencing a negative liquidity shock are more likely to reduce credit for firms that are smaller in size. Possible explanations could be that the continuation value of the relationship with a large firm is more valuable to the bank.

In columns 4 to 6 , we re-examine the effect on small vs. large firms but now we use thresholds based on the number of employees in a firm as of December 2006. In column 4, we use the threshold of 50 employees. In columns 5 and 6, we use thresholds of 100 and 250 employees respectively. We find once again that the coefficient on the interaction term is only significant for firms with less than 50 employees (column 4). We also find that the $\mathrm{F}$ test of the difference in coefficients is significant (at $10 \%$ level). We find similar results when we use the threshold of 100 employees (column 5). The results are more striking when we compare firms with more than 250 employees against firms with less than 250 employees (column 6). The coefficient on the dummy for firms with higher than 250 employees is $0.001 .^{23}$

The results above suggest that firms which borrowed more from banks with a higher interbank borrowing ratio before the crisis face a greater reduction in credit

\footnotetext{
${ }^{23} 250$ employees is the standard definition of small and medium enterprises according to the European Commission's Recommendation 2003/361/EC.
} 
supply, but this reduction primarily affects smaller (entrepreneurial) firms. An important question that arises is whether smaller firms also faced difficulties in establishing new lending relationships. In addition, it is also important to understand whether existing lending relationships of smaller firms were more likely to be terminated.

In Table 5, columns 1 to 3, we first examine the likelihood of firms establishing a new lending relationship. We define a new lending relationship as a dummy that takes the value of one if a firm has a loan from a bank that it had no lending relationship as on 2007, and zero otherwise. As in earlier regressions, we create dummies for firms with assets lower than the specified threshold, one dummy for firms with assets higher than the specified threshold. We then interact the dummies with interbank borrowing level. From columns 2 and 3, we see that the likelihood of establishing a new lending relationship is significantly lower for smaller firms. The $\mathrm{F}$ test of the difference in coefficients between small and large firms is significant at the $10 \%$ level. These results suggest that entrepreneurs' access to new credit in the banking system (the extensive margin of new lending relationships) is worsened by bank liquidity problems.

In columns 4 to 6 , Table 5 , we examine the likelihood of termination of an existing loan. As can be seen, we do not find any significant difference in the likelihood of termination of loans across small and large firms. ${ }^{24}$ In Table 6 , columns 1 to 3 , we examine whether strength of an existing credit relationship has an effect on the likelihood of termination. We proxy the strength of an existing credit relationship by the amount of credit outstanding between a firm-bank pair as on 2007. We also include firm fixed

\footnotetext{
${ }^{24}$ We find similar results if we use other thresholds reported in table 4.
} 
effects in the regressions. Thus, the variable, strength of the banking relationship, captures the fraction of borrowing from a bank as a fraction of the total firm borrowing. As compared to the Table 5, we now find that a firm borrowing from banks with higher level of interbank borrowing experiences a higher likelihood of loan termination. Interestingly, we find that higher strength of the banking relationship lowers the effect of interbank borrowing on likelihood of termination. We do not find significant differences across small and large firms. ${ }^{25}$ Thus, our results suggest that banking relationships ameliorate credit supply restrictions in the extensive margin of loan termination across all type of firms.

\subsection{Does the effect of interbank dependence on credit supply vary by bank}

\section{characteristics?}

While in Table 2 we find that there is a credit supply reduction for banks with higher interbank borrowing, in Table 7 we examine whether this effect varies by bank fundamentals. Several theoretical models predict that there are interactions between bank illiquidity and solvency (see e.g. Rochet and Vives 2004). We therefore interact interbank borrowing with different bank characteristics that proxy for fundamentals (column 1 to 6 reports the results).

We find that banks' ratio of non-performing assets and capital amplify the effect of interbank borrowing on credit supply. In column 4, we find that the effect of interbank

\footnotetext{
${ }^{25}$ Note that for the triple interactions, we include only two single variables (instead of three) as we are controlling for firm fixed effects (which captures whether the firm is large or small). Moreover, given that firm size is a dummy variable, we can put three double interactions and the triple one, or as we do in the table, we put two single and two triple interactions (the third double interaction, the one on interbank borrowing and relationship strength, is spanned by the two triples). In this way, we can see very clearly that the difference of the coefficient of the triple interaction for large firms is statistically (and economically) identical to the one for small firms.
} 
borrowing on credit supply reduction is higher for banks with higher level of nonperforming assets, i.e. higher likelihood of bank insolvency. We also find a higher effect of interbank borrowing on credit supply for banks with higher capital ratio. The finding that higher capital is associated with higher credit reduction could be due to banks that are riskier also hold higher capital due to regulatory and market pressures (see e.g. Iyer and Peydró 2011). Note that we do not find significant differences on the impact of interbank on credit supply with respect to bank size, liquid assets and return-on-assets ratio.

While the shock to the interbank funding led to a reduction in credit supply to firms, from a policy perspective it is important to understand how liquidity injections in the system by central banks (in this case the European Central Bank) affect credit supply. In column 6, we find that banks with higher overall borrowings from the central bank funding increase credit availability to firms. This effect, however, is partially reduced by higher ex-ante interbank borrowing (i.e., a negative coefficient of the double interaction). As we do not find that central bank funding alleviates the negative effect of interbank borrowing on credit supply, one possible explanation for this finding could be that banks with higher level of interbank borrowing also borrowed heavily from the central bank and held this additional liquidity in the form of liquid assets.

\subsection{How do banks manage their portfolio?}

An important question that arises is how banks rebalance their portfolio in response to the shock. While banks with higher interbank borrowing cut back on credit supply to firms, the question that arises is whether they also decrease their total assets or 
whether they hoard on liquidity. To address this question we examine at the bank level the total change in the bank assets and bank liquidity ratio between 2007 and 2009.

Table 8, column 1 presents the results of the change in the level of total bank assets. As results show, we do not find a significant effect of interbank borrowing on the change in total bank assets. ${ }^{26}$ This suggests that while banks cut back on credit supply to firms they did not reduce their total assets. In column 2, we examine the effect of interbank borrowing on the change in liquid assets. Interestingly we find that the coefficient is positive and significant. This suggests that banks used the liquidity availed from reduction in credit supply to firms to increase their liquidity asset ratio. This is consistent with models of liquidity hoarding and credit crunch during crises as e.g. Diamond and Rajan (2011). This finding holds relevance to the debate on liquidity provision by the central bank during a crisis. All in all, the evidence suggests that the negative effect of bank illiquidity on credit supply is not alleviated by central bank liquidity, but these banks hoard on more liquidity.

\subsection{Further robustness}

The results so far suggest that a dry up in interbank borrowing had a significant effect on credit supply for firms. However, given the nature of the shock, one could expect that there could be differences in the access banks have with respect to borrowing from foreign banks versus domestic banks. One of the concerns at the onset of the crisis was that lenders in the interbank market were worried about contagion due to counterparty risk or adverse selection. Thus one could expect that foreign sources of

\footnotetext{
${ }^{26}$ For some banks the data on their balance sheet characteristics is missing as on 2009:Q2.
} 
liquidity are more likely to dry up as against domestic sources. To examine this effect, we split the total borrowing in the interbank markets into borrowing from other domestic banks (headquarters in Portugal) and borrowing from foreign banks. We find that the level of borrowing from foreign banks (abroad) has a significant effect on credit (not reported). We also find similar results to that reported earlier for smaller firms (not reported).

To make sure that our results are not driven by the duration of the event window, we estimated our baseline specification across different windows, in particular before and after Bear Stearn and Lehman failures and also a couple of quarters before the initial shock of August 2007. We analyze the change in credit from 2007:Q1 to 2008:Q1, from 2007:Q2 to 2008:Q2, and from 2008:Q2 to 2009:Q2. We find that the coefficient on the impact of interbank borrowing on credit supply is statistically significant and economically important. As compared to the results reported in Table 2, the coefficient on interbank borrowing is similar in magnitude. All in all, the effects of interbank borrowing on credit supply are robust to the choice of event window.

\subsection{Are firms able to substitute the credit supply reduction?}

A crucial question that arises is whether firms that faced a credit supply reduction from affected banks were able to substitute credit from other, less affected, banks, or from other sources of finance as trade credit or market debt. For instance, imagine a firm that had two banking relationships before the crisis, one with a bank with high interbank borrowing, the other with a bank with no interbank borrowing. Is it possible that the firm could make up for the loss in credit from the bank with high interbank dependence via 
borrowing more from the other bank? Or can the firm create a new banking relationship? If so, one could find that there is no reduction in total credit available for the firm by looking across all the loans given to the firm from all the different banks.

To examine this issue, we first construct a measure of the average interbank exposure for each firm before the crisis. That is, for each firm we measure the (weighted) average of interbank exposure of banks that lend to that firm before the crisis (2007:Q2). Similarly, we construct the average interbank borrowing for foreign borrowing.

In Table 9, column 1, controlling for firm industry and location fixed effects, we find that firms that in the pre-crisis were borrowing more from banks with higher interbank borrowing faced a higher reduction in total credit from banks. In column 2, we find similar results controlling also for firm size, age and profitability. Hence, the results suggest that the credit supply reduction is binding. Notice that we can test this substitution effect since we observe all bank lending to each non-financial firm.

Still, despite that bank loans are the key source of external finance for firms in Portugal, especially for the smaller ones, firms could have compensated the reduction in bank credit supply with other sources of credit like trade credit or market debt. In column 3 we analyze whether the level of total debt of the firm in December 2008 is related to the average interbank borrowing of banks that were lending to the firm in 2007:Q2. Note that we control for the total level of debt in 2006. We find that firms that were borrowing more from banks with higher interbank borrowing (pre-crisis) experience a higher reduction in their total level of total debt. In column 4, we find similar results controlling also for firm size, age and profitability. The results suggest that, not only was bank credit 
supply reduced, but it was binding, i.e. firms could not compensate with credit from other banks nor from other sources of debt. In column 5 and 6 we find similar results if we use the pre-crisis average level of interbank borrowing from abroad.

All in all, these results suggest that firms on average are not able to perfectly substitute credit supply reductions from affected banks neither with credit form other less affected banks nor with other sources of debt. These results, therefore, suggest that negative liquidity shocks to banks have a disproportionate and binding effect on firms' access to credit.

\section{Conclusions}

A key channel through which a banking crisis may affect the economy relates to the ability of firms to access the credit. A central question in the current crisis is how the sudden dry up in interbank liquidity has impacted firm credit, especially for smaller younger entrepreneurial firms which might find it difficult to access funds from other sources and mainly rely on bank financing. In this paper, we analyze the effects of the 2007-09 banking crisis on the credit supply for firms.

For identification, we study loan level data using the entire bank lending in

Portugal, matched with relevant firm and bank information. We exploit the bank liquidity shock induced by the unexpected interbank crunch that started in August 2007. We measure the susceptibility to the shock by using the interbank liquidity dependence (borrowing) of each bank before the crisis. We use a difference-in-difference approach comparing lending before and after the crisis among banks with different level of 
interbank borrowing, and we control for heterogeneity in firm loan demand, net worth and risk by using firm fixed-effects.

Our results suggest that the interbank liquidity shock induced a credit supply contraction (both in the intensive and extensive margin), but primarily for entrepreneurial firms. Importantly, we find that these firms cannot compensate the reduction in loan supply via obtaining credit from other, less affected, banks, or from other sources of credit. In sum, our results suggest that the credit crunch was binding.

An important issue therefore is whether and how the liquidity coming from central banks, in this case the European Central Bank, helped in alleviating the credit supply tensions. Our evidence suggests that the negative impact of bank illiquidity on credit supply is stronger for banks with higher insolvency (higher non-performing loans). Consistent with this, we find limited positive overall effects from central bank liquidity on credit supply. Instead we find banks with higher ex-ante interbank dependence hoarding more liquid assets.

A policy implication of our results therefore is the design of alternative central banking and government mechanisms that increase the supply of credit to entrepreneurial firms as the central banks and governments of UK and the Euro area are lately devising. For example, the European Central Bank has lengthened the maturity of their loans to three years and expanded the set of collateral (to borrow from the ECB) to loans to SMEs, or in the UK banks can obtain public debt to use as collateral if they increase loans to SMEs. All these public policies try to increase the supply of credit to firms. Moreover, there are discussions on a new European directive on banks that is similar to 
the approach adopted recently in the Cyprus bank crisis, where there was a bail in from bank creditors and then a public recapitalization. Analyzing whether these public mechanisms work is a very interesting avenue for further exploration that we leave for future work.

\section{References}

Acharya, V. and D. Skeie, D. 2011. A model of liquidity hoarding and term premia in inter-bank markets. Journal of Monetary Economics 58: 436-47.

Acharya, V., and P. Schnabl. 2010. Do global banks spread global imbalances? The case of asset-backed commercial paper during the financial crisis of 2007-09. IMF Economic Review 58: 37-73.

Acharya, V., and O. Merrouche. 2012. Precautionary hoarding of liquidity and inter-bank markets: Evidence from the sub-prime crisis. CEPR Discussion Papers 8859.

Albertazzi, U. and D. J. Marchetti. 2011. Credit crunch, flight to quality and evergreening: An analysis of bank-firm relationships after Lehman. Mimeo.

Ashcraft, A., J. McAndrews, and D. Skeie. 2011. Precautionary reserves and the interbank market. Journal of Money, Credit, and Banking 43: 311-48.

Bernanke, B. 1983. Non-monetary effects of the financial crisis in propagation of the Great Depression. American Economic Review 73:257-76.

Bernanke, B., and C. S. Lown. 1991. The credit crunch. Brookings Papers on Economic Activity 22: 205-248.

Bernanke, B. S., M. Gertler, and S. Gilchrist. 1996. The financial accelerator and the flight to quality. Review of Economics and Statistics 78: 1-15.

Bertrand, M., E. Duflo, and S. Mullainathan. 2004. How much should we trust differences-in-differences estimates?. Quarterly Journal of Economics 119: 249-75.

BIS. 2012. Consolidated Banking Statistics. Bank for International Settlements. Basel, Switzerland. http://www.bis.org/statistics/consstats.htm.

Brunnermeier, M. 2009. Deciphering the liquidity and credit crunch of 2007-08. Journal of Economic Perspectives 23:77-100. 
Caballero, R. J., T. Hoshi, and A. K. Kashyap. 2008. Zombie lending and depressed restructuring in Japan. American Economic Review 98:1943-77.

Caballero, R. J., and A. Krishnamurthy. 2008. Collective risk management in a flight to quality episode. Journal of Finance 63: 2195-2230.

Calomiris, C., and J. Mason. 2003. Consequences of bank distress during the Great Depression. American Economic Review 93:937-947.

Cecchetti, S. 2008. Crisis and responses: the Federal Reserve and the financial crisis of 2007-2008. NBER Working Papers 14134, National Bureau of Economic Research, Inc.

Covitz, D., N. Liang, and G. Suarez. Forthcoming. The evolution of a financial crisis: Collapse of the asset-backed commercial paper market. Journal of Finance.

Dell'Ariccia, G., E. Detragiache, and R. Rajan. 2008. The real effects of banking crises. Journal of Financial Intermediation 17:89-112.

Diamond, D. and R. Rajan. 2011. Fear of fire sales, illiquidity seeking, and the credit freeze. Quarterly Journal of Economics 126: 557-91.

ECB. 2009. Financial Stability Review, European Central Bank, December.

ECB. 2009. Financial Integration Report, European Central Bank, April.

Freixas, X. and J. C. Rochet. 2008. Microeconomics of Banking. Cambridge MA: MIT Press.

Gan, J. 2007. The real effects of asset market bubbles: Loan- and firm-level evidence of a lending channel. Review of Financial Studies 20:1941-73.

Holmstrom, B. and J. Tirole. 2011. Inside and Outside Liquidity. Cambridge MA: MIT Press.

Ivashina, V., and D. S. Scharfstein. 2010. Bank lending during the financial crisis of 2008. Journal of Financial Economics 97: 319-338.

Iyer, R., and J.-L. Peydró. 2011. Interbank contagion at work: Evidence from a natural experiment. Review of Financial Studies 24: 1337-77.

Jiménez, G., S. Ongena, J.-L. Peydró, and J. Saurina. 2012a. Credit supply and monetary policy: Identifying the bank balance-sheet channel with loan applications. American Economic Review 102: 2301-26.

Jiménez, G., S. Ongena, J.-L. Peydró, and J. Saurina. 2012b. Hazardous times for monetary policy: What do twenty-three million bank loans say about the effects of monetary policy on credit risk-taking? Barcelona GSE working paper. 
Jiménez, G., A. Mian, J.-L. Peydró, and J. Saurina. 2012. Local versus aggregate lending channels: The effects of securitization on corporate credit supply. Barcelona GSE working paper.

Kashyap, A., and J. Stein, J. 2000. What do a million observations on banks say about the transmission of monetary policy? American Economic Review 90: 407-428.

Khwaja, A., and A. Mian. 2008. Tracing the impact of bank liquidity shocks: Evidence from an emerging market. American Economic Review 98: 1413-42.

Ongena, S., D. Smith, and D. Michalsen. 2003. Firms and their distressed banks: Lessons from the Norwegian banking crisis (1988-1991). Journal of Financial Economics 67:81-112.

Paravisini, D. 2008. Local bank financial constraints and firm access to external finance. Journal of Finance 63: 2161-2193.

Peek, J. and E. S. Rosengren. 2000. Collateral damage: Effects of the Japanese bank crisis on real activity in the United States. American Economic Review 90: 30-45.

Puri, M., J. Rocholl, and S. Steffen. 2011. Global retail lending in the aftermath of the US financial crisis: Distinguishing between supply and demand effects. Journal of Financial Economics 100:556-78.

Rochet, J.-C. and X. Vives. 2004. Coordination failures and the lender of last resort: Was Bagehot right after all? Journal of the European Economic Association 2:1116-47.

Schnabl, P. 2012. The international transmission of bank liquidity shocks: Evidence from an emerging market. Journal of Finance 67:897-932.

Upper, C. 2006. Contagion due to interbank credit exposures: What do we know, why do we know it, and what should we know? Mimeo, BIS.

Tirole, J. 2006. The Theory of Corporate Finance. Princeton, NJ: Princeton University Press. 


\section{Graph 1: Growth in Total Credit Volume for Non-financial Firms}

Growth in Credit

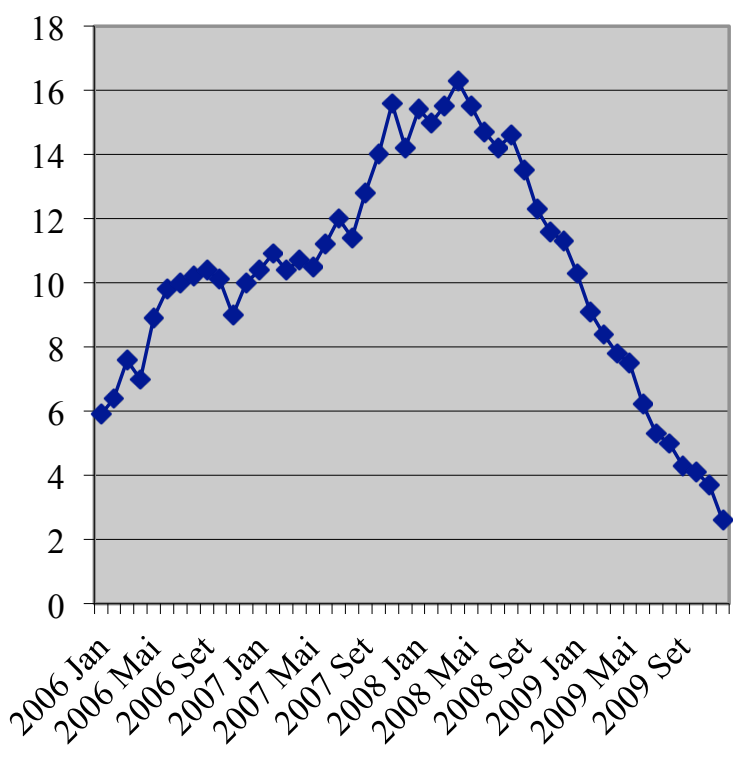

Graph 2: Interbank Borrowing (as a fraction of total assets)

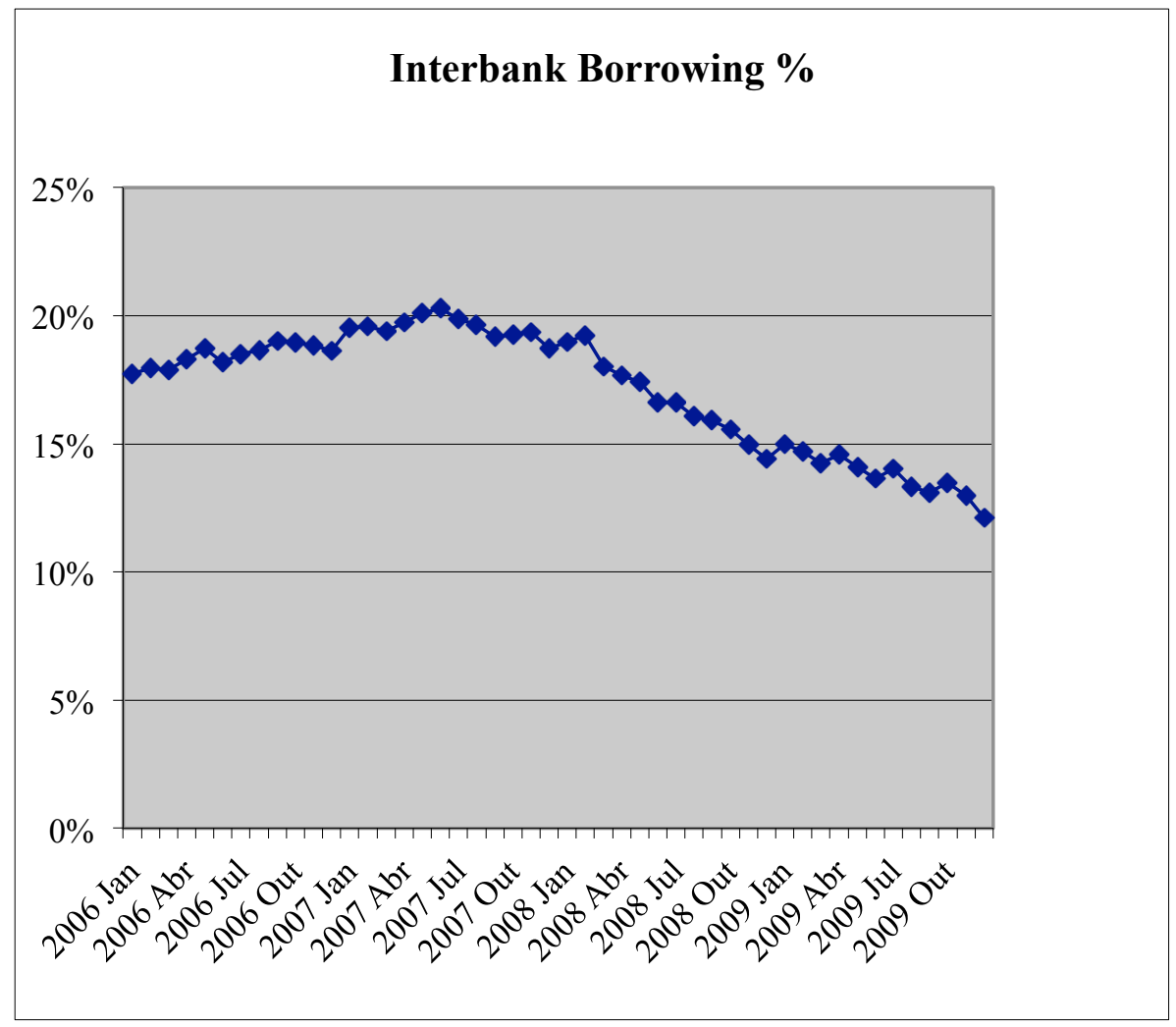




\section{Table 1: Summary Statistics}

No of banking relationships is the number of different banks that lend to a firm as on 2007:Q2, conditioning that the firm has any outstanding bank loan. Change in credit is the change in the ( $\log$ ) level of all the loans for each firm-bank pair between 2009:Q2 and 2007:Q2, where the initial interbank shock was August 2007. Interbank borrowing is the ratio of total interbank borrowing in 2007:Q2 for a bank; Foreign Interbank Borrowing is the part obtained abroad, and Domestic Interbank Borrowing is the part obtained from other banks in Portugal. Size is the log of total assets of the bank. Liquid assets are the ratio of cash to total assets of the bank. Return on Assets is the profits of the bank divided by its total assets. Non-performing loans is the fraction of loans that are in default as a fraction of total assets of the bank. Capital is the total bank capital as a fraction of total assets. All the bank variables are as of 2007:Q2. Firm Size is the log of total assets of the firm. Firm age is the age of the firm measured using the date of the firm's incorporation $(\ln (1+$ age $))$. Employees is the log of number of employees of a firm. All firm level variables are measured as on December 2006.

\begin{tabular}{lccc}
\hline & Mean & Median & Std. Dev \\
\hline No of Banking Relationships & 3.19 & 2 & 2.55 \\
Change in Credit & -0.16 & -0.02 & 1.20 \\
Interbank Borrowing & 0.25 & 0.05 & 0.31 \\
Foreign Interbank Borrowing & 0.27 & 0.18 & 0.26 \\
Domestic Interbank Borrowing & 0.12 & 0.006 & 0.13 \\
\hline Bank Size & 19.90 & 19.54 & 1.95 \\
Bank Liquid Assets & 0.29 & 0.31 & 0.22 \\
Bank Return on -Assets (ROA) & 0.005 & 0.004 & 0.005 \\
Bank Non Performing Loans (NPL) & 0.009 & 0.004 & 0.02 \\
Bank Capital & 0.11 & 0.09 & 0.10 \\
\hline Firm Size & 13.11 & 12.97 & 1.64 \\
Firm Employees & 1.918 & 1.791 & 1.20 \\
Firm Age & 2.470 & 2.484 & 0.77 \\
& & & \\
\hline \hline
\end{tabular}




\section{Table 2: Credit Supply Reduction and Total Interbank Borrowing}

This table presents results of OLS regressions, where the dependent variable is the change in the ( $\log$ ) level of committed credit volume for each firm-bank pair between 2009:Q2 and 2007:Q2, where the initial interbank shock was August 2007. Interbank borrowing is the ratio of interbank borrowing to total assets in 2007:Q2 for a bank. Size is the log of total assets of the bank. Liquid assets is the ratio of short-term to total assets of the bank. Return on Assets is the profits of the bank divided by its total assets. Non-performing loans is the fraction of loans that are in default as a fraction of total assets of the bank. Capital is the total bank capital as a fraction of total assets. Total firm-bank credit is the log of committed credit outstanding between a firm and a bank as of 2007:Q2. All the bank variables are as of 2007:Q2. Standard errors, reported in parentheses, are clustered at the bank level and heteroscedasticity-consistent. The symbols ***, $* *, *$ indicate significance levels at $1 \%, 5 \%$, and $10 \%$, respectively.

\begin{tabular}{|c|c|c|c|c|c|c|}
\hline & \multicolumn{6}{|c|}{$\begin{array}{l}\text { Change in the log level of firm-bank total credit volume } \\
\text { between 2009:Q2 and 2007:Q2 }\end{array}$} \\
\hline & (1) & (2) & (3) & (4) & (5) & (6) \\
\hline Interbank Borrowing & $\begin{array}{l}-0.558^{* * *} \\
(0.118)\end{array}$ & $\begin{array}{l}-0.556^{* * *} \\
(0.123)\end{array}$ & $\begin{array}{l}-0.329 * * * \\
(0.100)\end{array}$ & $\begin{array}{l}-0.623 * * * \\
(0.122)\end{array}$ & $\begin{array}{l}-0.371 * * * \\
(0.112)\end{array}$ & $\begin{array}{l}-0.554 * * * \\
(0.129)\end{array}$ \\
\hline Bank Size & & & $\begin{array}{l}0.065^{* * *} \\
(0.019)\end{array}$ & & $\begin{array}{l}0.070^{* * *} \\
(0.019)\end{array}$ & $\begin{array}{c}0.087 \\
(0.024)\end{array}$ \\
\hline Bank Liquid Assets & & & $\begin{array}{l}0.284 \\
(0.291)\end{array}$ & & $\begin{array}{l}0.337 \\
(0.345)\end{array}$ & $\begin{array}{l}0.320 \\
(0.437)\end{array}$ \\
\hline Bank Return on Assets & & & $\begin{array}{l}11.087 \\
(7.142)\end{array}$ & & $\begin{array}{l}11.252 \\
(8.967)\end{array}$ & $\begin{array}{c}0.643 \\
(9.553)\end{array}$ \\
\hline Bank Non-performing Assets & & & $\begin{array}{l}3.181^{* *} \\
(1.347)\end{array}$ & & $\begin{array}{l}3.678 * * * \\
(1.267)\end{array}$ & $\begin{array}{l}3.983 * * * \\
(1.346)\end{array}$ \\
\hline Bank Capital & & & $\begin{array}{l}-0.472 \\
(0.857)\end{array}$ & & $\begin{array}{l}-0.542 \\
(0.948)\end{array}$ & $\begin{array}{l}-0.859 \\
(1.207)\end{array}$ \\
\hline Total firm-bank credit 2007:Q2 & & & & & & $\begin{array}{l}-0.207^{* * *} \\
(0.017)\end{array}$ \\
\hline Adj R2 & 0.012 & 0.020 & 0.020 & 0.086 & 0.095 & 0.156 \\
\hline No of Banking Relationships $>1$ & No & Yes & Yes & Yes & Yes & Yes \\
\hline Firm Fixed effects & No & No & No & Yes & Yes & Yes \\
\hline Number of Obs & 293,896 & 220,406 & 220,406 & 220,406 & 220,364 & 220,364 \\
\hline
\end{tabular}




\section{Table 3: Credit Supply Reduction across different Firms and Total Interbank Borrowing}

This table presents results of OLS regressions, where the dependent variable is the change in the ( $\log$ ) level of committed credit volume for each firm-bank pair between 2009:Q2 and 2007:Q2, where the initial interbank shock was August 2007. Interbank borrowing is the ratio of interbank borrowing to total assets in 2007:Q2 for a bank. Firm Size is the log of total assets of the firm. Firm Age is the age of the firm measured using the date of the firm's incorporation $(\ln (1+$ age $))$. Employees is the log of number of employees of a firm. Firm Interest Coverage is defined as firm gross profit divided by interest expense on loans. Firm ROA is the profits of the firm divided by its total assets. Firm-Bank Credit is the log of credit outstanding between a firm and a bank as of 2007:Q2. The sample is restricted in all regression to firms that have at least 2 banking relationships. All regression includes controls for bank characteristics (non-reported) and, in column 6, we also include the Bank-Firm credit as of 2007:Q2 as an independent variable. All firm level variables are measured as on December 2006. Standard errors, reported in parentheses, are clustered at the bank level and heteroscedasticity-consistent. The symbols $* * *, * *, *$ indicate significance levels at $1 \%, 5 \%$, and $10 \%$, respectively.

\begin{tabular}{|c|c|c|c|c|c|c|}
\hline \multicolumn{7}{|c|}{$\begin{array}{l}\text { Change in the log level of firm-bank total credit volume } \\
\text { between 2009:Q2 and 2007:Q2 }\end{array}$} \\
\hline & (1) & (2) & (3) & (4) & (5) & (6) \\
\hline Interbank Borrowing & $\begin{array}{l}-1.521^{* * *} \\
(0.452)\end{array}$ & $\begin{array}{l}-0.563^{* * *} \\
(0.146)\end{array}$ & $\begin{array}{l}-0.499 * * * \\
(0.124)\end{array}$ & $\begin{array}{l}-0.365^{* * *} \\
(0.119)\end{array}$ & $\begin{array}{l}-0.365^{* * *} \\
(0.117)\end{array}$ & $\begin{array}{l}-0.435^{* * *} \\
(0.110)\end{array}$ \\
\hline Firm Size* Interbank Borr & $\begin{array}{l}0.083^{* *} \\
(0.034)\end{array}$ & & & & & \\
\hline Firm Age* Interbank Borr & & $\begin{array}{l}0.080^{* *} \\
(0.038)\end{array}$ & & & & \\
\hline Firm Employees* Interbank Borr & & & $\begin{array}{c}0.056 \\
(0.037)\end{array}$ & & & \\
\hline Firm Int Coverage*Interbank Borr & & & & $\begin{array}{l}-0.075^{* * *} \\
(0.011)\end{array}$ & & \\
\hline Firm ROA* Interbank Borr & & & & & $\begin{array}{l}-0.140 \\
(0.118)\end{array}$ & \\
\hline Firm-Bank Credit* Interbank Borr & & & & & & $\begin{array}{l}0.088^{* * *} \\
(0.019)\end{array}$ \\
\hline Adj R2 & 0.095 & 0.095 & 0.095 & 0.095 & 0.095 & 0.095 \\
\hline Firm Fixed effects & Yes & Yes & Yes & Yes & Yes & Yes \\
\hline Number of Obs & 154,434 & 154,434 & 154,434 & 154,434 & 154,434 & 154,434 \\
\hline
\end{tabular}




\section{Table 4: Credit Supply Reduction, Interbank Borrowing \& Firm Size (Total Assets \& Number of Employees)}

This table presents results of OLS regressions, where the dependent variable is the change in the ( $\log$ ) level of committed credit volume for each firm-bank pair between 2009:Q2 and 2007:Q2. We use different firm size thresholds measured as on December 2006 to create dummy variables. For e.g. in column 1 we have two dummy variables that we interact with interbank borrowing, the first one is a dummy for firms with total assets less than one million euros and the second is a dummy for firms with total assets more than one million euros. Columns 1 to 3 use thresholds based on total assets of the firm. Columns 4 to 6 use thresholds based on number of firm employees as on December 2006. Interbank borrowing is the ratio of interbank borrowing in 2007:Q2 for a bank. Size is the log of total assets of the bank. Liquid assets is the ratio of shortterm to total assets of the bank. Return on Assets is the profits of the bank divided by its total assets. Non-performing loans is the fraction of loans that are in default as a fraction of total assets of the bank. Capital is the total bank capital as a fraction of total assets. All the bank variables are as of 2007:Q2. The sample is restricted in all regression to firms that have at least 2 banking relationships. Standard errors, reported in parentheses, are clustered at the bank level and heteroscedasticity-consistent. The symbols $* * *, * *, *$ indicate significance levels at $1 \%, 5 \%$, and $10 \%$, respectively.

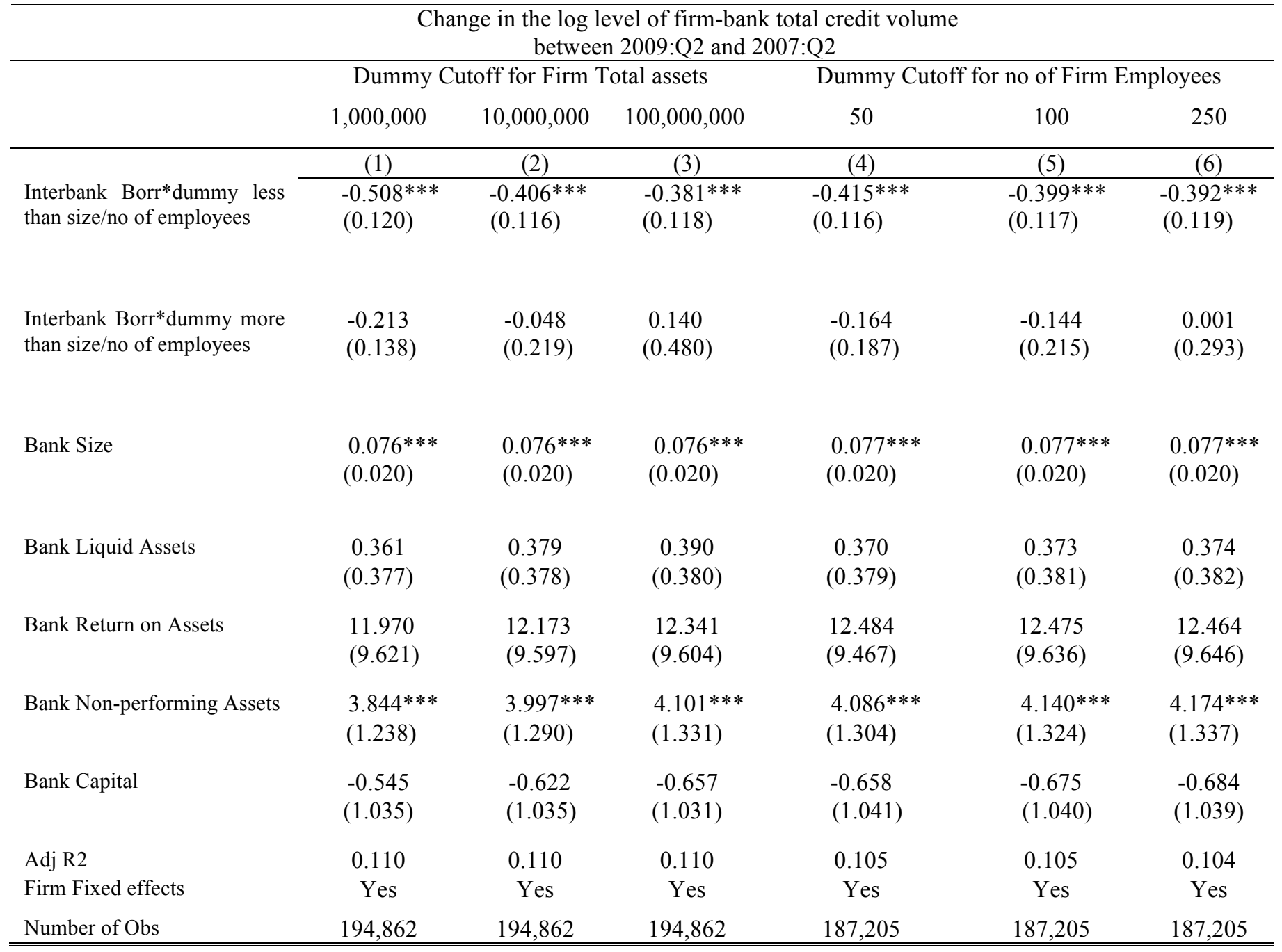


Table 5: The Extensive Margin, Interbank Borrowing \& Firm Size

This table presents results of OLS regressions, where New Lending Relationships is a dummy that takes the value of one if the firm has a new loan as on 2009:Q2 with a bank that it had no loan as on 2007:Q2, and Termination of Existing Lending Relationship takes the value of one if the firm had a loan with a bank as on 2007:Q2 and has no loan with the bank as on 2009:Q2. In column 2, we interact interbank borrowing with a dummy for firms with total assets less than ten million euros and the second interaction is that of interbank borrowing with a dummy for firms with total assets more than ten million euros (same for column 5). In column 3, we interact interbank borrowing with a dummy for firms with no of employees less than hundred and the second interaction is that of interbank borrowing with dummy for firms with no of employees more than hundred (same for column 6). Both total assets and no of employees are measured as on December 2006. Interbank borrowing is the ratio of interbank borrowing in 2007:Q2 for a bank. Size is the log of total assets of the bank. Liquid assets is the ratio of short-term to total assets of the bank. Return on Assets is the profits of the bank divided by its total assets. Nonperforming loans is the fraction of loans that are in default as a fraction of total assets of the bank. Capital is the total bank capital as a fraction of total assets. All the bank variables are as of 2007:Q2. The sample is restricted in all regression to firms that have at least 2 banking relationships. Standard errors, reported in parentheses, are clustered at the bank level and heteroscedasticity-consistent. The symbols $* * *, * *, *$ indicate significance levels at $1 \%, 5 \%$, and $10 \%$, respectively.

\begin{tabular}{|c|c|c|c|c|c|c|}
\hline \multicolumn{4}{|c|}{ New Lending Relationships } & \multicolumn{3}{|c|}{ Termination of Existing Lending Relationship } \\
\hline & & Size & $\begin{array}{l}\text { No of } \\
\text { employees }\end{array}$ & & Size & $\begin{array}{c}\text { No of } \\
\text { Employees }\end{array}$ \\
\hline & (1) & (2) & (3) & (4) & (5) & (6) \\
\hline Interbank Borrowing & $\begin{array}{l}-0.008 \\
(0.005)\end{array}$ & & & $\begin{array}{c}0.083 \\
(0.057)\end{array}$ & & \\
\hline $\begin{array}{l}\text { Interbank Borr*dummy less } \\
\text { than size/no of employees }\end{array}$ & & $\begin{array}{r}-0.009^{*} \\
(0.005)\end{array}$ & $\begin{array}{l}-0.008^{*} \\
(0.005)\end{array}$ & & $\begin{array}{c}0.066 \\
(0.060)\end{array}$ & $\begin{array}{l}0.068 \\
(0.061)\end{array}$ \\
\hline $\begin{array}{l}\text { Interbank Borr*dummy more } \\
\text { than size/no of employees }\end{array}$ & & $\begin{array}{l}0.003 \\
(0.009)\end{array}$ & $\begin{array}{r}-0.0004 \\
(0.008)\end{array}$ & & $\begin{array}{l}0.085 \\
(0.056)\end{array}$ & $\begin{array}{c}0.081 \\
(0.058)\end{array}$ \\
\hline Bank Size & $\begin{array}{c}0.001 \\
(0.0008)\end{array}$ & $\begin{array}{l}0.001 \\
(0.0008)\end{array}$ & $\begin{array}{c}0.001 \\
(0.0008)\end{array}$ & $\begin{array}{l}-0.028 * * * \\
(0.007)\end{array}$ & $\begin{array}{l}-0.030 * * * \\
(0.007)\end{array}$ & $\begin{array}{l}-0.031 * * * \\
(0.007)\end{array}$ \\
\hline Bank Liquid Assets & $\begin{array}{l}-0.004 \\
(0.009)\end{array}$ & $\begin{array}{l}-0.003 \\
(0.010)\end{array}$ & $\begin{array}{l}-0.002 \\
(0.010)\end{array}$ & $\begin{array}{l}-0.040 \\
(0.114)\end{array}$ & $\begin{array}{l}-0.077 \\
(0.128)\end{array}$ & $\begin{array}{l}-0.079 \\
(0.130)\end{array}$ \\
\hline Bank Return on Assets & $\begin{array}{l}1.284 * * \\
(0.579)\end{array}$ & $\begin{array}{c}1.464 * * \\
(0.578)\end{array}$ & $\begin{array}{l}1.473^{* *} \\
(0.580)\end{array}$ & $\begin{array}{l}-0.529 \\
(5.513)\end{array}$ & $\begin{array}{l}-0.771 \\
(5.439)\end{array}$ & $\begin{array}{l}-0.867 \\
(5.497)\end{array}$ \\
\hline Bank Non-performing Assets & $\begin{array}{c}0.043 \\
(0.047)\end{array}$ & $\begin{array}{c}0.053 \\
(0.049)\end{array}$ & $\begin{array}{l}0.056 \\
(0.049)\end{array}$ & $\begin{array}{c}0.539 \\
(1.334)\end{array}$ & $\begin{array}{c}0.434 \\
(1.318)\end{array}$ & $\begin{array}{l}0.444 \\
(1.321)\end{array}$ \\
\hline Bank Capital & $\begin{array}{l}-0.024 \\
(0.035)\end{array}$ & $\begin{array}{l}-0.025 \\
(0.035)\end{array}$ & $\begin{array}{l}-0.024 \\
(0.034)\end{array}$ & $\begin{array}{l}0.459 \\
(0.496)\end{array}$ & $\begin{array}{l}0.552 \\
(0.517)\end{array}$ & $\begin{array}{c}0.561 \\
(0.522)\end{array}$ \\
\hline $\begin{array}{l}\text { Adj R2 } \\
\text { Firm Fixed effects }\end{array}$ & $\begin{array}{c}0.133 \\
\text { Yes }\end{array}$ & $\begin{array}{c}0.116 \\
\text { Yes }\end{array}$ & $\begin{array}{c}0.111 \\
\text { Yes }\end{array}$ & $\begin{array}{c}0.125 \\
\text { Yes }\end{array}$ & $\begin{array}{c}0.132 \\
\text { Yes }\end{array}$ & $\begin{array}{c}0.130 \\
\text { Yes }\end{array}$ \\
\hline Number of Obs & 222242 & 196689 & 188976 & 296825 & 259779 & 248908 \\
\hline
\end{tabular}


Table 6: The Extensive Margin and Strength of Banking Relationships

This table presents results of OLS regressions, where Termination of Existing Lending Relationship takes the value of one if the firm had a loan with a bank as on 2007:Q2 and has no loan with the bank as on 2009:Q2. In column 2 and 3 we interact with Interbank borrowing and Relationship strength with a dummy for firms with total assets less than ten million euros and the second interaction is with dummy for firms with total assets more than ten million euros. In column 3 and 4, we interact interbank borrowing and Relationship strength with a dummy for firms with no of employees less than hundred and the second interaction is with dummy for firms with no of employees more than hundred. Both total assets and no of employees are measured as on December 2006. Relationship strength is the log of credit outstanding between a firm and a bank as of 2007:Q2. Interbank borrowing is the ratio of interbank borrowing in 2007:Q2 for a bank. Size is the log of total assets of the bank. Liquid assets is the ratio of short-term to total assets of the bank. Return on Assets is the profits of the bank divided by its total assets. Nonperforming loans is the fraction of loans that are in default as a fraction of total assets of the bank. Capital is the total bank capital as a fraction of total assets. All the bank variables are as of 2007:Q2. The sample is restricted in all regression to firms that have at least 2 banking relationships. Standard errors, reported in parentheses, are clustered at the bank level and heteroscedasticity-consistent. The symbols $* * *, * *, *$ indicate significance levels at $1 \%, 5 \%$, and $10 \%$, respectively.

\begin{tabular}{|c|c|c|c|}
\hline & \multicolumn{3}{|c|}{ Termination of Existing Lending Relationship } \\
\hline & & Size & No of Employees \\
\hline & (1) & (2) & (3) \\
\hline $\begin{array}{l}\text { Interbank Borr*dummy less than threshold } \\
* \text { Relationship strength }\end{array}$ & & $\begin{array}{l}-0.055^{* *} \\
(0.026)\end{array}$ & $\begin{array}{l}-0.052^{* *} \\
(0.024)\end{array}$ \\
\hline $\begin{array}{l}\text { Interbank Borr*dummy more than threshold } \\
\text { * Relationship strength }\end{array}$ & & $\begin{array}{l}-0.053^{* * *} \\
(0.014)\end{array}$ & $\begin{array}{l}-0.070^{* * *} \\
(0.018)\end{array}$ \\
\hline Interbank Borr*Relationship strength & $\begin{array}{l}-0.051 * * \\
(0.022)\end{array}$ & & \\
\hline Interbank Borrowing & $\begin{array}{l}0.519 * * \\
(0.238)\end{array}$ & $\begin{array}{l}0.547 * * \\
(0.273)\end{array}$ & $\begin{array}{l}0.524^{* *} \\
(0.258)\end{array}$ \\
\hline Relationship strength & $\begin{array}{c}-0.066^{* * *} \\
(0.008)\end{array}$ & $\begin{array}{l}-0.070 * * * \\
(0.009)\end{array}$ & $\begin{array}{c}-0.069 * * * \\
(0.008)\end{array}$ \\
\hline $\begin{array}{l}\text { Interbank Borrowing*dummy more than } \\
\text { threshold }\end{array}$ & & $\begin{array}{l}0.120 \\
(0.251)\end{array}$ & $\begin{array}{l}0.308 \\
(0.248)\end{array}$ \\
\hline $\begin{array}{l}\text { Relationship strength*dummy more than } \\
\text { threshold }\end{array}$ & & $\begin{array}{l}0.041^{* * *} \\
(0.006)\end{array}$ & $\begin{array}{l}0.037 * * * \\
(0.007)\end{array}$ \\
\hline Bank Size & $\begin{array}{l}-0.021 * * * \\
(0.005)\end{array}$ & $\begin{array}{l}-0.022 * * * \\
(0.005)\end{array}$ & $\begin{array}{l}-0.021^{* * *} \\
(0.005)\end{array}$ \\
\hline Bank Liquid Assets & $\begin{array}{l}-0.043 \\
(0.086)\end{array}$ & $\begin{array}{l}-0.042 \\
(0.086)\end{array}$ & $\begin{array}{l}-0.044 \\
(0.087)\end{array}$ \\
\hline Bank Return on Assets & $\begin{array}{l}-3.293 \\
(5.365)\end{array}$ & $\begin{array}{l}-3.178 \\
(5.308)\end{array}$ & $\begin{array}{l}-3.423 \\
(5.387)\end{array}$ \\
\hline Bank Non-performing Assets & $\begin{array}{l}0.334 \\
(0.935)\end{array}$ & $\begin{array}{l}0.399 \\
(0.934)\end{array}$ & $\begin{array}{l}0.368 \\
(0.935)\end{array}$ \\
\hline Bank Capital & $\begin{array}{c}0.042 \\
(0.364)\end{array}$ & $\begin{array}{l}0.027 \\
(0.366)\end{array}$ & $\begin{array}{l}0.052 \\
(0.369)\end{array}$ \\
\hline Adj R2 & 0.232 & 0.234 & 0.234 \\
\hline Firm Fixed effects & Yes & Yes & Yes \\
\hline Number of Obs & 259779 & 259779 & 248904 \\
\hline
\end{tabular}




\section{Table 7: Differential Effects of Interbank Dependence on Credit Supply by Bank Characteristics}

This table presents results of OLS regressions, where the dependent variable is the change in the ( $\log$ ) level of committed credit volume for each firm-bank pair between 2009:Q2 and 2007:Q2, where the initial interbank shock was August 2007. Interbank borrowing is the ratio of interbank borrowing to total assets in 2007:Q2 for a bank. Size is the log of total assets of the bank. Liquid assets is the ratio of short-term to total assets of the bank. Return on Assets is the profits of the bank divided by its total assets. Non-performing loans is the fraction of loans that are in default as a fraction of total assets of the bank. Capital is the total bank capital as a fraction of total assets. Total firm-bank credit is the log of committed credit outstanding between a firm and a bank as of 2007:Q2. Central Bank Borr is the liquidity availed by a bank from the European Central Bank. All the bank variables are as of 2007:Q2. All regression includes controls for bank characteristics (non-reported). All firm level variables are measured as on December 2006. Standard errors, reported in parentheses, are clustered at the bank level and heteroscedasticityconsistent. The symbols $* * *, * *, *$ indicate significance levels at $1 \%, 5 \%$, and $10 \%$, respectively.

\begin{tabular}{|c|c|c|c|c|c|c|}
\hline & \multicolumn{5}{|c|}{$\begin{array}{c}\text { Change in the log level of firm-bank total credit volume } \\
\text { between 2009:Q2 and 2007:Q2 }\end{array}$} & \\
\hline & (1) & (2) & (3) & (4) & (5) & (6) \\
\hline Interbank Borrowing & $\begin{array}{l}-0.832 \\
(1.957)\end{array}$ & $\begin{array}{l}-0.442^{* * *} \\
(0.155)\end{array}$ & $\begin{array}{l}-0.149 \\
(0.172)\end{array}$ & $\begin{array}{l}-0.292 * * \\
(0.124)\end{array}$ & $\begin{array}{c}0.034 \\
(0.203)\end{array}$ & $\begin{array}{l}-0.373 * * * \\
(0.132)\end{array}$ \\
\hline Bank Size* Interbank Borr & $\begin{array}{l}0.021 \\
(0.089)\end{array}$ & & & & & \\
\hline Bank Liq Assets* Interbank Borr & & $\begin{array}{c}0.616 \\
(0.918)\end{array}$ & & & & \\
\hline Bank ROA* Interbank Borr & & & $\begin{array}{l}-47.013 \\
(34.247)\end{array}$ & & & \\
\hline Bank NPL* Interbank Borr & & & & $\begin{array}{r}-18.615^{*} \\
(9.582)\end{array}$ & & \\
\hline Bank Capital* Interbank Borr & & & & & $\begin{array}{c}-6.304 * * \\
(2.694)\end{array}$ & \\
\hline Central Bank Borr & & & & & & $\begin{array}{l}0.027 * * * \\
(0.009)\end{array}$ \\
\hline $\begin{array}{l}\text { Central Bank Borr* Interbank } \\
\text { Borr }\end{array}$ & & & & & & $-0.081 * *$ \\
\hline & & & & & & $(0.033)$ \\
\hline Adj R2 & 0.095 & 0.095 & 0.096 & 0.096 & 0.097 & 0.114 \\
\hline Firm Fixed effects & Yes & Yes & Yes & Yes & Yes & Yes \\
\hline Number of Obs & 220,284 & 220,284 & 220,284 & 220,284 & 220,284 & 182,343 \\
\hline
\end{tabular}




\section{Table 8: Rebalancing of Bank Portfolio}

This table presents results of OLS regressions, where the dependent variable is the change in the level of bank total assets and bank liquid assets between 2009:Q2 and 2007:Q2, where the initial interbank shock was August 2007. Interbank borrowing is the ratio of interbank borrowing to total assets in 2007:Q2 for a bank. Size is the log of total assets of the bank. Liquid assets is the ratio of short-term to total assets of the bank. Return on Assets is the profits of the bank divided by its total assets. Non-performing loans is the fraction of loans that are in default as a fraction of total assets of the bank. Capital is the total bank capital as a fraction of total assets. All the bank variables are as of 2007:Q2. Robust standard errors, reported in parentheses, are heteroscedasticity-consistent. The symbols $* * *, * *, *$ indicate significance levels at $1 \%, 5 \%$, and $10 \%$, respectively.

\begin{tabular}{lcc}
\hline \hline & $\begin{array}{c}\text { Change in } \\
\text { bank total } \\
\text { assets }\end{array}$ & $\begin{array}{c}\text { Change in } \\
\text { bank liquid } \\
\text { assets }\end{array}$ \\
\hline \multirow{2}{*}{ Interbank Borrowing } & $(1)$ & $(2)$ \\
\cline { 2 - 3 } Bank Size & $(0.128$ & $0.066^{*}$ \\
& & $(0.033)$ \\
Bank Liquid Assets & & 0.001 \\
& & $(0.005)$ \\
Bank Return on Assets & -0.171 & \\
Bank Non-performing Assets & $(0.323)$ & \\
& -18.369 & $3.718^{*}$ \\
Bank Capital & $(12.469)$ & $(2.117)$ \\
Adj R2 & 0.020 & 0.263 \\
Number of Obs & $(1.326)$ & $(0.363)$ \\
\hline \hline
\end{tabular}




\section{Table 9: Credit Substitution, Total Supply Reduction \& Interbank Borrowing}

This table presents results of OLS regressions, where the dependent variable in Column 1, 2 and 5 is the change in the log of total bank loan volume for each firm between 2009:Q2 and 2007:Q2 (where the initial interbank shock was in August 2007), whereas in Column 3, 4 and 6 is the $\log$ of overall debt of the firm outstanding as on December 2008 (includes bank debt and other forms of debt from suppliers as trade credit, etc). Average Interbank Borrowing is, for each firm, the weighted (by loan size) average level of interbank borrowing of the banks in May 2007 that are lending to the firm in 2007:Q2. Average Foreign Interbank Borrowing is as Average Interbank Borrowing but only using the interbank funds borrowed from foreign banks. Firm ROA is the return of assets of the firm. Firm Age is the age of the firm measured using the date of the firm's incorporation $(\ln (1+\mathrm{age}))$. Total Firm Debt is the log of total firm debt outstanding (including all forms of debt). Firm Size is the log of assets of the firm. All firm level controls are measured as on December 2006. All regressions are estimated with dummies for geographic location and the industry of the firm. The sample is restricted in all regressions to firms that have at least 2 banking relationships. White heteroscedasticity-consistent robust standard errors are reported in parentheses. $* * *, * *, *$ indicate significance levels at $1 \%, 5 \%$, and $10 \%$ respectively.

\begin{tabular}{|c|c|c|c|c|c|c|}
\hline & $\begin{array}{c}\text { Change in } \\
\text { Total Bank } \\
\text { debt }\end{array}$ & $\begin{array}{c}\text { Change in } \\
\text { Total Bank } \\
\text { debt }\end{array}$ & $\begin{array}{l}\text { Total Firm } \\
\text { Debt } 2008\end{array}$ & $\begin{array}{l}\text { Total Firm } \\
\text { Debt } 2008\end{array}$ & $\begin{array}{c}\text { Change in } \\
\text { Total Bank } \\
\text { debt }\end{array}$ & $\begin{array}{l}\text { Total Firm } \\
\text { Debt } 2008\end{array}$ \\
\hline & (1) & (2) & (3) & (4) & (5) & (6) \\
\hline Average Interbank Borrowing & $\begin{array}{l}-0.576^{* * *} \\
(0.032)\end{array}$ & $\begin{array}{l}-0.636^{* * *} \\
(0.043)\end{array}$ & $\begin{array}{l}-0.510^{* * *} \\
(0.032)\end{array}$ & $\begin{array}{l}-0.037 * * \\
(0.018)\end{array}$ & & \\
\hline $\begin{array}{l}\text { Average Foreign Interbank } \\
\text { Borr }\end{array}$ & & & & & $\begin{array}{l}-0.361 * * * \\
(0.052)\end{array}$ & $\begin{array}{l}-0.074 * * * \\
(0.023)\end{array}$ \\
\hline Firm ROA & & $\begin{array}{l}-0.189 * * * \\
(0.065)\end{array}$ & & $\begin{array}{l}-0.003 \\
(0.012)\end{array}$ & $\begin{array}{c}-0.145^{* *} \\
(0.065)\end{array}$ & $\begin{array}{l}-0.003 \\
(0.012)\end{array}$ \\
\hline Firm Age & & $\begin{array}{l}-0.056^{* * *} \\
(0.009)\end{array}$ & & $\begin{array}{l}-0.076 * * * \\
(0.003)\end{array}$ & $\begin{array}{l}-0.046 * * * \\
(0.009)\end{array}$ & $\begin{array}{l}-0.075 \\
(0.003)\end{array}$ \\
\hline Firm Size & & $\begin{array}{l}-0.093 \\
(0.253)\end{array}$ & & $\begin{array}{l}0.164 * * * \\
(0.039)\end{array}$ & $\begin{array}{l}-0.089 \\
(0.253)\end{array}$ & $\begin{array}{l}0.164 * * * \\
(0.039)\end{array}$ \\
\hline Total Firm Debt & & & & $\begin{array}{l}0.926^{* * *} \\
(0.003)\end{array}$ & & $\begin{array}{l}0.925^{* * *} \\
(0.023)\end{array}$ \\
\hline Adj R2 & 0.008 & 0.011 & 0.365 & 0.845 & 0.009 & 0.845 \\
\hline Firm Industry Fixed effects & Yes & Yes & Yes & Yes & Yes & Yes \\
\hline Firm Location Fixed effects & Yes & Yes & Yes & Yes & Yes & Yes \\
\hline Number of Obs & 108,878 & 74,912 & 70,958 & 61,312 & 74,912 & 61,312 \\
\hline
\end{tabular}

